\title{
Revisiting the limping parental condition of unmarried fathers
}

\author{
Anne Louw \\ $B A$ (Stell) Bluris (UNISA) LLB LLD (Pret) \\ Associate Professor, Department of Private Law, University of Pretoria
}

\begin{abstract}
OPSOMMING
'n Herbesinning van die hinkende ouerlike status van ongetroude vaders

Die oogmerk van artikel 21 van die Kinderwet was om die gemenereg so te ontwikkel dat ten minste betrokke ongetroude vaders ook deur regswerking as die ouers van hulle biologiese kinders erken kan word by geboorte. Die wetgewer het egter hierdie proses bemoeilik deur die dubbelsinnige en onduidelike terme wat in die bepaling gebesig word. Die groeiende aantal sake waarin die howe genader word vir die opheldering van die inhoud van artikel 21 is bewys hiervan en kom as geen verrassing nie. Die artikel gee 'n kritiese oorsig oor hierdie uitsprake wat nog grotendeels ongerapporteer is. Die mening word gehuldig dat die reg in terme van artikel 21 nie net ongeregverdig teen ongetroude vaders diskrimineer op grond van geslag en getroude status nie, maar ook teen ongetroude moeders en veral die kinders van sulke vaders. Daar word geargumenteer dat vaders op dieselfde basis as moeders ouerlike status behoort te verkry bloot op grond van die biologiese band met die kind. Indien dispute tussen die ouers ontstaan oor die uitoefening van hulle verantwoordelikhede en regte kan mediasie, 'n ouerskapplan of selfs die hof genader word om te bepaal wat is in die beste beland van die kind. Tot tyd en wyl artikel 21 ongrondwetlik verklaar word, sal die hinkende ouerlike status van ongetroude vaders egter voortduur. Die gevolgtrekking wat bereik word is dat alhoewel die uitsprake van die howe kan help met die uitleg van artikel 21, dit nie kan kompenseer vir die onderliggende gebrek aan objektiewe kriteria vir die verkryging van ouerlike verantwoordelikhede en regte deur ongetroude vaders nie.
\end{abstract}

\section{Introduction}

Section 21 of the Children's Act ${ }^{1}$ was intended to develop the common law to allow at least committed unmarried fathers to become the legal parents of their biological children by operation of law. Unmarried fathers who qualify within the terms set by the Children's Act can thus currently acquire full parental responsibilities and rights on the same basis as mothers at the birth of their child. The importance of establishing a child's legal parentage with the highest degree of certainty at the earliest possible moment cannot be overestimated. The legislator has unfortunately complicated the process in the case of unmarried biological fathers by the vague and ambiguous terminology employed in

138 of 2005 , hereafter the Children's Act.

How to cite: Louw 'Revisiting the limping parental condition of unmarried fathers' 
section 21.2 The interpretational difficulties and increased litigation which have resulted were predicted. ${ }^{3}$ Very few of the judgments have been reported. The extent of the problem is thus not readily apparent. This comment attempts to set the record straight by showing how the courts have interpreted and applied section 21 to determine what has been referred to as the "parental condition'4 of unmarried fathers in recent times.

\section{Preliminary Considerations}

\section{The Question of Urgency}

It is one of the general principles of the Children's Act that a delay in any matter concerning a child must be avoided as far as possible. ${ }^{5}$ There are numerous examples of court orders relating to children being granted on

2 Discussed in detail in Louw Acquisition of Parental Responsibilities and Rights (LLD thesis UP 2009) 115-133. See also Heaton 'Parental Rights and Responsibilities' in Davel \& Skelton (eds) Commentary on Children's Act (2007) 3-11 to 3-15; and Skelton 'Parental Rights and Responsibilities' in Boezaart (ed) Child Law in South Africa (2009) 75-77.

3 See Louw (LLD thesis) supra 2 at $124 \& 133$.

4 A phrase used by the court in GMv KI 20153 SA 62 (GJ) parr $10 \& 19$. The use of the phrase is not explained by the court, possibly considering it superfluous. Despite the court's apparent confusion between the content of parental responsibilities and rights as defined in s 18(2) (par 10) and the acquisition thereof as regulated by s 21 of the Children's Act in the case of unmarried fathers (par 19), the phrase 'parental condition' seems to have been used as a substitute for the more clumsy phrase 'acquisition of parental responsibilities and rights', introduced by the Children's Act (see heading of Part I of Ch 3 of Children's Act). While other more common substitutes such as 'legal parentage', 'parenthood; and 'parental status' are commonly used internationally, they are rarely employed in South African legal discourse (recently only in the context of surrogacy; see Ex parte MS 2014 (3) SA 415 (GP) parr $37 \& 67$ and Ex parte WH 20116 SA 514 (GNP) par 52). However, it is perhaps unwise to use the phrases interchangeably. Only a biological link can e.g. create rights of intestate succession. As such, even if non-parents acquire full parental responsibilities and rights they will still not acquire 'parental status' in the true sense of the word. 'Parental status' should thus, strictly speaking, only be reserved for biological parents who have acquired full parental responsibilities and rights and persons who are by statutory decree placed in the same position as such parents. With regard to the latter category of persons deemed to be parents, it is noteworthy that the definition of 'parent' in s 1(1) of the Children's Act only includes an adoptive parent. Since the commissioning parents in the case of a confirmed full surrogate motherhood agreement (s 297(1) read with s 298) and the consenting spouse of a woman who is artificially fertilised (s 40(1)) also fall in this category, the definition is not inclusive enough and should be amended. For purposes of this article 'parental condition', in relation to an unmarried father, will refer to the acquisition of full parental responsibilities and rights by the unmarried father or the parental status of such a father.

5 S 6(4)(b). 
an urgent basis. ${ }^{6}$ Some of the divisions of the high court, moreover, in express terms treat certain issues pertaining to children as urgent. The high court in the Western Cape, for example, has been instructed as a general rule to treat all applications brought pursuant to the provisions of the Hague Convention on the Civil Aspects of International Child Abduction 1980 as urgent matters. ${ }^{7}$ The court in $M v V$ (born $\left.N\right)^{8}$ was even prepared to go so far as to state that all matters concerning children are, by their very nature, urgent.

While the court's decision to hear the matter in Goliath $v$ Hutchinson ${ }^{9}$ on an urgent basis cannot be faulted, ${ }^{10}$ the issue of urgency was much more controversial in Sullivan $v$ Olivier. ${ }^{11}$ In Sullivan, a mother approached the court on an urgent basis to declare herself and the biological father of the child co-holders of parental responsibilities and rights and to make certain orders pertaining to the exercise of contact and care and the payment of maintenance. The parents were in a permanent life-partnership at the time of the child's birth so the 'parental condition' of the unmarried father was not disputed in this case. The court indicated that the decision to hear the application on an urgent basis was solely based on the averment by the mother ${ }^{12}$ that she and the child had been subjected to harm at the instance of the respondent "who ha[d] threatened to remove the minor child from the care of the

$6 \quad$ See Desai v Desai 19874 SA 178 (T); Davy v Douglas 19991 SA 1043 (N); Centre for Child Law v Minister of Home Affairs 20056 SA 50 (T); and C $v$ Department of Health and Social Development, Gauteng 20122 SA 208 (CC).

7 See Note 36 of the Western Cape High Court, Cape Town Consolidated Practice Notes effective as from 2013-05-01.

8 [2011] JOL 27045 (WCC) par 7.

9 Unreported case 280/2011 [2011] ZAECGHC 12 (3 March 2011).

10 In this case, the biological father and the paternal grandmother of a child approached the court on an urgent basis to grant an order pending the outcome of an inquiry by the family advocate into the permanent arrangements for 'custody' and 'family responsibilities' in respect of the child (par 1). The child had been living with his paternal grandmother from the age of one year. This long-term close relationship had been disrupted by the child's biological mother who had removed the child to stay with his maternal grandmother without the consent of the child's father (parr 3-4). In considering the urgency and the merits of the application, the court reiterated that 'primary' consideration (par 8) must be given to the best interests of the child and the list of factors mentioned in $\mathrm{s} 7$ of the Children's Act. Surprisingly, however, the court reverted to a consideration of the relevant factors mentioned in McCall $v$ McCall 19943 SA 201 (C) $205 \mathrm{~A}$ - the precursor to s 7 . After investigating the circumstances of the child in some detail, Andrews AJ found, quite understandably, the matter to be urgent based on the following considerations: The tender age of the child, the uncertainty of his current circumstances and the potential detrimental effect of a disruption in the stability and security of his home and family circumstances (par 16). The court thus ordered the child to be returned to his paternal grandmother pending the outcome of the investigation by the family advocate (parr $16 \& 17$ ).

11 Unreported case EL 1107/2013 ECD2607/2013 [2013] ZAECELLC 7 (10 September 2013).

12 Idem par 6. 
applicant'. ${ }^{13}$ Answering to a claim on behalf of the respondent that the matter should be dismissed on the basis that the application was not urgent, the court, with reference to Revenue Services $v$ Hawker Air Services, ${ }^{14}$ held that even if the application brought by way of urgency turns out not to be urgent, 'there is no salutary practice that such an application has to be dismissed on the grounds of lack of urgency alone'. 15

Rejecting the application was never considered an option in this case since the court was satisfied that the application had been properly filed as an urgent matter. ${ }^{16}$ However, because the father contested the allegations of threat of harm to the mother and/or the child, the matter could not be dispensed with on an urgent basis since it would have to be referred for oral evidence. ${ }^{17}$ The court held that the issue of the exercise of the parents' responsibilities and rights could ultimately best be addressed by the family advocate. ${ }^{18}$ As such, the court deemed it sufficient merely to grant interim relief. Pre-empting the possible rejection of the application if the court found no urgency in the matter, it was argued on behalf of the applicant that preventing her from approaching the court for relief that related to maintenance would amount to unfair discrimination against unmarried parents. The court rejected the contention that the applicant's position should be equated with that of a married woman seeking interim relief by means of rule 43 proceedings, ${ }^{19}$ quite correctly in the opinion of the current author, based on the fact that there was no matrimonial action pending. ${ }^{20}$ Despite the various provisions in the Children's Act, the court emphasised the fact that it is in no way limited by any law in making any order relating to children, ${ }^{21}$ including the maintenance of a child - "even if it is a provisional order ... pending finalisation of the maintenance court enquiry'. 22 Tshiki $\mathrm{J}$ was of the opinion that maintenance matters involving children should be dealt with 'as expeditiously as is practically possible'. 23 It was perhaps because proceedings in the maintenance court in general cannot be expedited that the court in this case was willing to issue an interim order relating to maintenance as well. ${ }^{24}$

The case seems to confirm suspicions that parents (probably on the advice of their legal counsel) increasingly prefer to approach the high court directly to resolve disputes relating to children. The advantages of choosing this course of action would seem to override the burden of

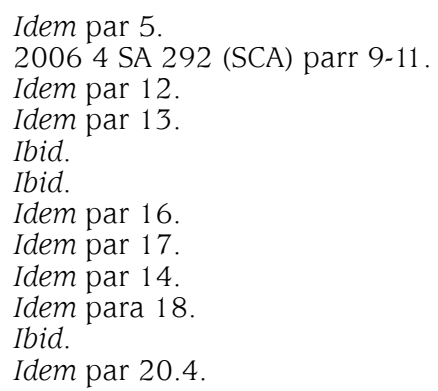


additional costs it involves. Moreover, the willingness displayed by the courts to entertain the notion of urgency in matters relating to children could mean that the relief can be obtained speedily - even if, as suggested by the court in Sullivan $v$ Olivier, it turns out that there was never any real urgency in the matter. Furthermore, the high court can, for example, entertain and grant applications for relief relating to parental responsibilities and rights and maintenance simultaneously while such relief would require initiating proceedings in different courts on a lower level. An additional bonus would be the more (if only perceived) competent bench hearing the application. The procedure in the high court is being used notwithstanding the fact that the lower courts have concurrent jurisdiction to grant relief in such matters. In this case there was no dispute regarding the parental status of the parents. The dispute centred around the possible risk of harm to the child which could have been addressed either by a protection order issued by the magistrate's court in terms of the Domestic Violence Act ${ }^{25}$ or an order by the children's court in terms of section 45(1)(a) of the Children's Act. The disputes relating to the exercise of care and contact and the payment of support in express terms fall within the jurisdiction of the children's court $^{26}$ and, presumably, also the maintenance court. ${ }^{27}$ While the high court's jurisdiction as the upper guardian of minors naturally is not and cannot be limited in any way, ${ }^{28}$ the court in $F S v J J^{29}$ cautioned against a practice of forum-shopping 'even in cases concerning disputes over parenting rights and responsibilities'. The case involved a series of applications and counter applications over a period of nearly five years of litigation in the Northern and Western Cape High Courts during and after finalisation of a children's court inquiry. The unmarried father preempted the children's court inquiry by approaching the high court for a declaratory order to confirm his parental status in terms of section 21 which had by that stage come into operation. The grandparents, on their part, used the opportunity presented by the postponement of the father's application to hijack the outcome by lodging a claim of their own in another division of the high court. Succeeding on appeal against all of the orders made up to that point, the court confirmed that the unmarried father was the holder of full responsibilities and rights and granted the grandparents contact with their grandchild on a regular basis. ${ }^{30}$ Lewis JA provided the following general guidelines as far as the practice of 'forumhopping or forum-shopping' was concerned:

High courts should not in general be faced with litigation requiring them in effect to set aside an order made in another jurisdiction. And as a rule, since one is entitled to assume that any order has been made in the best interests

25116 of 1998.

26 S 45(1)(b) \& (d) of the Children's Act.

27 S 15 of the Maintenance Act 99 of 1998.

28 S 45(4) of the Children's Act.

292011 (3) SA 126 (SCA) par 38.

30 Idem par 55. 
of a child, should those interests change over time, the court that made the initial order should be approached for a variation. ${ }^{31}$

The court was nonetheless convinced that the difficulties in this regard would be resolved by the enactment of section 29 of the Children's Act. ${ }^{32}$ Section 29 deals with 'court proceedings' relating to applications brought by interested persons to acquire or terminate parental responsibilities and rights. ${ }^{33}$ In such cases, the jurisdiction of the court in question - be it the children's court, the divorce court or the high court - would be determined by the place where the child is ordinarily resident. ${ }^{34}$ Section 21 does not provide the same guidance. Section 21(3)(b) merely makes provision for the outcome of the mediation, which must first be sought in case of a dispute, ${ }^{35}$ to be reviewed by 'a court'. Where section 29 could not assist, Lewis JA indicated that 'reliance on formalism and a resort to inflexible rules is to be discouraged'. 36

The judiciary as well as experts in the field have alluded to the jurisdictional uncertainties and anomalies created by the Children's Act. ${ }^{37}$ With the notable exception of issues relating to guardianship, ${ }^{38}$ the children's courts and the high courts have concurrent jurisdiction as far as disputes relating to care, contact, and support are concerned. Section 1(4) of the Children's Act confuses matters even further by prohibiting a children's court from dealing with matters arising out of the application of the Divorce Act, ${ }^{39}$ the Maintenance $\mathrm{Act}^{40}$ or the Domestic Violence Act. ${ }^{41}$ Thus, while an unmarried father may approach the children's court, for example, for a variation of a contact order, a

\section{Idem par 38.}

32 Ibid.

33 In terms of s 22(4)(b) (by means of a parental responsibilities and rights agreement), s 23 (care or contact), s 24 (guardianship), s 26(1)(b) (application to confirm paternity in cases where mother cannot or will not consent to amendment of birth registration) and s 28 (termination of parental responsibilities and rights).

34 S 29(1).

35 S 21(3)(a).

36 Reference is made to the now well-known dictum by Sachs J in $A D v D W$ (Centre for Child Law as Amicus Curiae; Department for Social Development as Interested Party) 20083 SA 183 (CC) par 30 that a child's best interests 'should not be mechanically sacrificed on the altar of jurisdictional formalism'. The majority of the court in $A D$ concluded that while the children's court was the correct forum to consider applications for intercountry adoption, the high court could still hear such matters in 'exceptional cases' (par 34).

37 Ex parte Sibisi 20111 SA 192 (KZP) par 14; Sloth-Nielsen 'The Jurisdiction of the Regional Courts Amendment Act, 2008: some implications for child law and divorce jurisdiction' 2011 Journal for Juridical Science 1; and Gallinetti 'The Children's Court' in Commentary on the Children's Act RS 5 (2012) 4-4 to 4-5 \& 4-9 to 4-10. See also Louw (LLD thesis) supra $n 2$ at 282 \& 297-299.

38 S 45(3) of the Children's Act.

3970 of 1979 .

4099 of 1998.

41116 of 1998. Sloth-Nielsen 2011 Journal for Juridical Science 7 refers to the position as 'schizophrenic'. 
divorced father must presumably go back to the court that originally granted the divorce order. ${ }^{42}$ Unmarried fathers, therefore, would seem to have more options when choosing a forum. ${ }^{43}$ The problem created by the Children's Act granting concurrent jurisdiction to several courts is clearly different from the more serious problem of the actual 'forum shopping' which occurred in the FS case. The possibility of using one of several courts - or only the high court ${ }^{44}$ - to obtain relief, merely impedes on the right of poor litigants to access justice on an equitable basis. ${ }^{45}$ It is evident that the more wealthy applicants are able to avoid the problems that beset the fragmented, and possibly less competent, adjudication of matters in the lower courts by simply approaching the high court directly. Restricting access to the high court would be counterproductive and challenge the high court's role as the upper guardian of all children. Proposing the creation of a family court with comprehensive jurisdiction is of no use whatsoever given the lack of political will to effect such a dramatic change to the resolution of family law disputes in South Africa. Legislative reform would thus sadly seem to be the only viable, albeit less ideal, solution at this stage. ${ }^{46}$

\section{Historical Context}

In accordance with the dictates of statutory interpretation, both the high court in $I v C^{47}$ and the Supreme Court of Appeal (SCA) ${ }^{48}$ considered it of some importance to place section 21 in historical context before tackling the issues in dispute. Reference is made ${ }^{49}$ to the common law denying unmarried fathers inherent rights, the enactment of (the since repealed) Natural Fathers of Children Born out of Wedlock Act ${ }^{50}$ and the Fraser case $(\mathrm{s})^{51}$ catapulting the rights of at least committed fathers into the constitutional domain. ${ }^{52}$ According to the SCA, the legislator clearly

42 S 8(2) of the Divorce Act 70 of 1979.

43 See Skelton 'Parental Rights and Responsibilities' in Boezaart (supra n 2) 83.

44 According to Skelton (idem 81) 'the sole jurisdiction of the high court presents a barrier to access to justice for some of the poorest and most vulnerable children'.

45 S 34 read with s 9 of the Constitution of the Republic of South Africa, 1996 (hereafter the Constitution).

46 See Ex parte Sibisi supra n 37 at par 14; and Sloth-Nielsen 2011 Journal for Juridical Science 17.

47 Unreported case 11137/2013 [2014] ZAKZDHC 11 (4 April 2014) par 18.

48 KLVC v SDI [2015] 1 All SA 532 (SCA) par 18.

49 Parr $19 \& 18$ respectively.

5086 of 1997.

51 Fraser $v$ Children's Court, Pretoria North 1997 (2) SA 261 (CC).

52 Echoing the sentiments expressed in the Fraser case, the South African Law Commission (as it was then called) concluded that "at the current stage of South African societal and economic development, the mere existence of a biological tie should not in itself be sufficient to justify the automatic vesting of all parental responsibilities and rights in the father, where the father has not availed himself of the opportunity of developing a relationship with his extra-marital child and is willing to shoulder the responsibilities of the parental role': SALC Discussion Paper on the Review of the Child Care Act par 8.5.2.1. 
intended 'to accord an unmarried father similar rights and responsibilities ( $\mathrm{sic}$ ) in relation to his child to those of the father who was married to the child's mother' and 'to promote both the equality guarantee in s 9 and, more importantly, the right of a child to parental care as envisaged by s 28 of the Constitution'. 53

\section{Section 21}

\section{Origin of Disputes Relating to Section 21}

Section 21 became relevant in RRS $v D A L^{54}$ and $I v C^{55}$ in rather surprising circumstances. In both these cases the court had to decide whether the child in question had been wrongfully removed from the Republic in terms of the Hague Convention on the Civil Aspects of International Child Abduction, $1980 .{ }^{56}$ For this purpose, the court had to determine whether the unmarried father had been possessed of, and was actually exercising, 'rights of custody' as defined in Articles 3 and 5 of the Convention when the child was removed from South Africa. In a more expected application of section 21, the court in Rudi $v$ Sonja ${ }^{57}$ had to determine whether the unmarried father had ex lege acquired parental responsibilities and rights at the birth of the child following the mother's abrupt termination of the father's contact with his child.

Because of its importance to the ensuing discussion, section 21 is reproduced here for ease of reference:

21 Parental responsibilities and rights of unmarried fathers

(1) The biological father of a child who does not have parental responsibilities and rights in respect of the child in terms of section 20 , acquires full parental responsibilities and rights in respect of the child-

(a) if at the time of the child's birth he is living with the mother in a permanent life-partnership; or

(b) if he, regardless of whether he has lived or is living with the mother-

(i) consents to be identified or successfully applies in terms of section 26 to be identified as the child's father or pays damages in terms of customary law;

(ii) contributes or has attempted in good faith to contribute to the child's upbringing for a reasonable period; and

(iii) contributes or has attempted in good faith to contribute towards expenses in connection with the maintenance of the child for a reasonable period.

(2) This section does not affect the duty of a father to contribute towards the maintenance of the child.

(3)(a)If there is a dispute between the biological father referred to in subsection (1) and the biological mother of a child with regard to the fulfillment by that father of the conditions set out in subsection (1)(a) or

$53 I \mathcal{V}$ C supra $\mathrm{n} 47$ at par 19

54 Unreported case 22994/2010 [2010] ZAWCHC 618 (10 December 2010).

55 Supra $n 47$.

56 Incorporated into domestic law in terms of s 274 of the Children's Act.

57 Unreported case 115/13 [2014] ZANWHC 3 (9 January 2014). 
(b), the matter must be referred for mediation to a family advocate, social worker, social service professional or other suitably qualified person.

(b) Any party to the mediation may have the outcome of the mediation reviewed by a court.

(4) This section applies regardless of whether the child was born before or after the commencement of this Act.

[Date of commencement of s. 21: 1 July 2007.]

\section{Interpretational Guidance}

\section{Section 21(1)(a): Living Together at the Time of the Child's Birth}

In the cases mentioned in the previous paragraph where compliance with the requirements in terms of section 21 was disputed, none of the parents were living in a permanent life-partnership at the time of the birth of the child. This requirement has consequently received little or no attention by the judiciary. The court in both $J E v N M^{58}$ and Sullivan $v$ Olivier $^{59}$ simply, on the version of the parties in question, accepted that the unmarried father had become a co-holder of parental responsibilities and rights based on the fact that he was living with the mother at the time of the child's birth. Because the issue was not in dispute, no inquiry into the exact nature of the relationship was launched in any of the cases. The absence of a clear definition of the concept of a 'permanent lifepartnership' thus seems to be less of a problem in practice than initially anticipated. ${ }^{60}$ On the other hand, it could be argued that the requirement has simply been diluted to a requirement of cohabitation, making a further investigation into the permanence or otherwise of the relationship unnecessary. Proposals recommending that the provision be amended along these lines would seem to support such a contention. ${ }^{61}$ The proposal to dilute the requirement should be welcomed. Not only would it avoid the almost impossible task of having to define the concept but it would also remove an unnecessary hindrance placed in the path of unmarried fathers to acquire parental status at the child's birth.

\section{Section 21(1)(b)}

\section{Three-in-one Requirement?}

The court in RRS $v D A L$ held, without deliberating the issue, that all three requirements stated in section 21(1)(b) must be complied with for an unmarried father to acquire parental responsibilities and rights. ${ }^{62}$ The

\footnotetext{
58 Unreported case 38571/2013 [2014] ZAGPJHC 175 (20 June 2014) par 4.

59 Sullivan $v$ Olivier supra $n 11$ at par 3.

60 See Louw (LLD thesis) supra n 2 at 116-117; Heaton 'Parental Rights and Responsibilities' in Davel \& Skelton (supra n 2) 3-13; and Skelton 'Parental Rights and Responsibilities' in Boezaart (supra n 2) 75.

61 This amendment will allegedly form part of the proposed Third Children's Amendment Bill currently being finalised by the Department of Social Development.

62 RRS $v$ DAL supra $\mathrm{n} 54$ at $\mathrm{p} 13$, lines $2-4$.
} 
court in $I \mathcal{V} C$, on the other hand, canvassed the arguments for and against such a proposition in some detail. It was contended on behalf of the unmarried father that:

the use of the word "and" in section 21 denotes no more than a signal by the legislature that a Court must have regard to all three categories and that a negative conclusion regarding one did not preclude the granting of relief on the strength of the others. ${ }^{63}$

This point of view was based, firstly, on the judgment in Klerck $v$ Klerck ${ }^{64}$ in which the court held that the factors that had to be considered in the case of a forfeiture of benefits at divorce, ${ }^{65}$ that were also linked with the word 'and', should be read disjunctively. ${ }^{66}$ Moreover, it was contended no special significance could be attached to the word 'and' in section 21 and that using 'or' instead of 'and' would not have solved the problem either. ${ }^{67}$ If the requirements were joined with 'or' it would have implied that the factors should be regarded as alternatives which it was alleged clearly could not have been the intention of the legislature in this case. $^{68}$

Opposing counsel countered by arguing that section 21 means what it says and that the use of the word 'and' meant that all three requirements had to be met. ${ }^{69}$ The dictum in RRS was used to support this view. Referring to Guardrisk Insurance Company Limited $v$ Registrar of Medical Schemes ${ }^{70}$ it was argued that in the absence of compelling reasons to the contrary, words in legislation should carry their ordinary meaning. The judgment in Klerck was distinguished on the basis that section 9 of the Divorce Act conferred a discretion on the court, which clearly was absent in section $21 .{ }^{71}$ Gabriel AJ was inclined to agree with this point of view. ${ }^{72}$ He was not convinced that the value judgment that had to be made by the court, when interpreting the broad concepts used in section 21 , amounted to the exercise of a judicial discretion, as argued by applicant's counsel. ${ }^{73}$ The court a quo ultimately found it unnecessary to decide whether the subsection should be read conjunctively since even if the matters referred to in section 21(1)(b)(i)-(iii) were self-standing and distinct requirements, the unmarried father had met them all. ${ }^{74}$ The high court, however, did not exclude the possibility that a case with different facts may well turn on 'these jurisprudential arguments'. ${ }^{75}$ On appeal

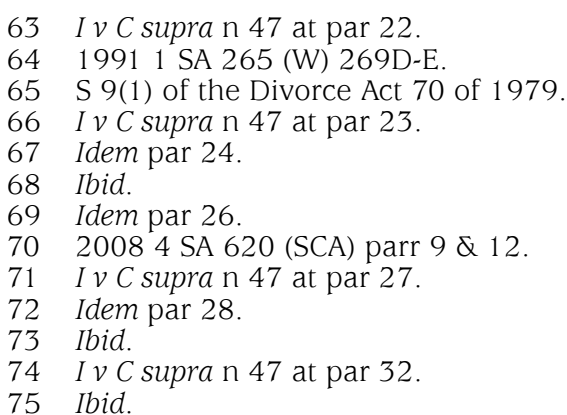


against this judgment, the majority in $K L V C \vee S D I$ concurred with this view:

It is a type of matter which can only be disposed of on a consideration of all the relevant factual circumstances of the case. An unmarried father either acquires parental rights or responsibilities or he does not. Clearly, judicial discretion has no role in such an enquiry - it is therefore an entirely factual enquiry. ${ }^{76}$

The question of whether section 21(1)(b) can be read disjunctively poses a dilemma. While a disjunctive reading would have the benefit of opening up additional opportunities for an unmarried father to be recognised as the other legal parent, it is difficult to see how the use of the word 'and' connecting the requirements can readily be ignored.

\section{Section 21(1)(b)(i): Identification as Father}

The cumulative listing of the requirements in section 21(1)(b) did not deter the court in GM $v K I^{77}$ simply to accept without more that the unmarried father acquired full parental responsibilities and rights when he consented to being identified as the child's father. In this case the unmarried father's name appeared on the child's birth registration and the child was registered under his surname. ${ }^{78}$ The court assumed that the father had acquired full parental responsibilities and rights despite the fact that he had never lived with the mother ${ }^{79}$ and that he had shown a lack of commitment to the child and did not maintain him or take any interest in his wellbeing. ${ }^{80}$ There seems to be a popular misconception that a father whose name appears on the child's birth certificate is automatically also the legal father of the child. The birth registration process is aimed (at least where a naturally conceived child is concerned) at identifying the biological mother and father of the child - nothing more. The fact that a certain man is identified as the child's biological father will definitely not necessarily mean that he is also the legal father of the child. He can only acquire parental status if he is the birth mother's spouse or satisfies the requirement of section 21 . The position of an unmarried father in South Africa is thus distinguishable from the position of such fathers in the United Kingdom where birth registration will automatically confer parental responsibility on the father. ${ }^{81}$ Although the issue has not conclusively been settled, as shown above, it seems that being identified as the father is only one of a triad of requirements listed

\footnotetext{
76 KLVC v SDI [2015] 1 All SA 532 (SCA) par 14.

77 GMv KI supra $\mathrm{n} 4$ at par 3.

78 Although not expressly mentioned at the outset the child was also registered under the surname of the father. The eventual order to change the surname of the child makes this assumption inevitable (idem par 4).

79 Idem par 2.

80 According to the judgment (idem par 2) the respondent 'essentially abandoned the Applicant and the child and is currently untraceable'.

81 S 4(1)(a) of the U.K. Children Act 1989.
} 
in section 21(1)(b) that have to be satisfied to acquire legal parentage in South Africa. The new Immigration Regulations ${ }^{82}$ which became effective on 1 June 2015, also seem to proceed from the premise that parents whose names appear on a child's birth certificate are necessarily the child's guardians and must therefore consent to the minor being removed from the Republic. According to Regulation 6(12)(b), where only one parent is travelling with a child the parent must produce an unabridged birth certificate and:

(i) consent in the form of an affidavit from the other parent registered as a parent on the birth certificate of the child authorising him or her to enter into or depart from the Republic with the child he or she is travelling with;

(ii) a court order granting full parental responsibilities and rights or legal guardianship in respect of the child, if he or she is the parent or legal guardian of the child.

The regulations therefore require an unmarried mother who travels with her child to provide a sworn, written statement by the biological father of the child consenting to the travel, unless the mother can produce a court order showing that she has full parental responsibilities and rights in respect of the child. The consent of the father will be required in all cases where his name appears on the birth certificate, regardless of the fact that he is not the legal father of the child in terms of section 20 or 21 of the Children's Act. Furthermore, it should be noted that a court order granting full parental responsibilities and rights or legal guardianship will not necessarily give the parent accompanying the child the right to travel abroad without the consent of the other parent - only an order granting the accompanying parent sole responsibilities and rights or sole legal guardianship will have that result. ${ }^{83}$

The mother in GMv KI applied in terms of section 28 of the Children's Act to terminate the rights that the father had supposedly acquired at the child's birth. ${ }^{84}$ The application was motivated by a desire to protect the child against a father with an allegedly 'criminal disposition' who, in the mother's (by the court's own admission wholly unsubstantiated) opinion, could go so far as 'selling the child if he were allowed to take care of him without my supervision' ${ }^{85}$ However, based on the mistaken assumption that the father had acquired full parental responsibilities and rights, the more real inconvenience to the mother was caused by her believing that

82 Published in GG 37679 GN R413 2014-05-26.

83 In terms of regulation $6(12)(\mathrm{d})$, any unaccompanied minor must produce to the immigration officer proof of consent from one or both his or her parents or legal guardian, as the case may be. However, where one parent provides proof of consent, that parent must also provide a copy of a court order issued to him or her in terms of which he or she has been granted full parental responsibilities and rights in respect of the child.

$84 G M v K I$ supra $n 4$ at par 3.

85 Idem par 2.9 . 
she had to obtain the consent of the absent father every time she wanted to travel to family in Zambia. ${ }^{86}$

With reference to the definitional section 1(1) read with section 18 of the Children's Act, the court held - quite correctly in the view of the present author - that 'parental responsibilities and rights are, for the most part, two sides of the same coin' ${ }^{87}$ The other sections in the Act, including section $28,{ }^{88}$ refer to parental responsibilities and rights conjunctively. ${ }^{89}$ In the court's opinion, therefore, it is 'clearly neither desirable nor (sic) practicable to attempt to define which of the incidence of the parental condition is "right" and which "obligation", 90 The court recognised that to terminate rights but leave the responsibilities intact 'would be difficult, if not impossible' to apply. ${ }^{91}$

The reason for emphasising the indivisibility of parental responsibilities and rights arose as a result of the applicant's initial wish to terminate the rights, but not the responsibilities, of the child's father. In particular it would seem, the mother did not wish to terminate the responsibility of the father to maintain the child. Since the father's rights could not be terminated without also terminating all the father's responsibilities, Fisher AJ considered it better to suspend, rather than terminate, the father's responsibilities and rights. ${ }^{92}$ If all the responsibilities and rights were merely suspended, they could be revived at a later date. In the present circumstances, it was deemed appropriate to link the suspension of the father's parental responsibilities and rights to the child's maintenance requirements ${ }^{93}$ - i.e. when the father reappeared and started making a contribution to the maintenance of the child. ${ }^{94}$ The court acknowledged the uncertainty which could be created when having to establish 'for purposes of dealing with third parties' whether or not the suspension had ceased to operate. ${ }^{95}$ However, the court considered this uncertainty 'sometimes unavoidable' in the context of determining the status of unmarried fathers 'being as it is dependent on factors not readily apparent'. 96 In the court's view, such uncertainties could be resolved either 'by way of affidavit or other means of satisfying third parties' or '[a]s a last resort the court can be approached for clarity'. 97

86 Idem par 2.10

87 Idem par 14.

88 Idem par 12

89 Idem par 11.

90 Idem par 10.

91 Idem par 14.

92 Idem par 17.

93 Ibid.

94 Idem par 18.

95 Idem par 16.

96 Ibid.

97 Ibid. The motivation behind these statements is hard to gather. The continued reference to third parties in this context is baffling to say the least. While it may conceivably sometimes be necessary for an unmarried father to defend his position against third parties (as suggested in n 4) it 
While the court acceded that the obligation to maintain a child is not normally affected by whether that parent is allowed to exercise other parental responsibilities and rights, "the contribution by a father to his child's maintenance cannot be underestimated in relation to its importance to the parental condition'. ${ }^{98}$ The statement is substantiated with reference to the importance given to the making of a contribution to the maintenance of the child that is in terms of section 21(1)(b)(iii) regarded 'as momentous enough to bring about the acquisition by the unmarried father of full parental responsibilities and rights where they previously did not exist'. 99 Fisher AJ was not prepared to accept the express assurance in section 21(2) that the provisions of section 21 do not affect the duty of a father to contribute to the maintenance of the child. While he sensed that the duty to maintain would survive a blanket termination of all parental responsibilities and rights, he contended that the position was not clear. ${ }^{100}$ The proposed order for suspension was thus deemed in order because it operates 'to preserve the right to claim, at least, future maintenance'. ${ }^{101}$

The reported judgment is intended to provide the reasons for the orders made by the court in response to the "unusual' 102 request by the applicant's attorneys. Not willing to decide on whether the applicant was entitled to such reasons, Fraser AJ nevertheless acceded to the request 'because the matter involved the fundamental rights of a child as well as important considerations relating to the interpretation of the Act'. ${ }^{103}$ The judgment can and should thus be considered obiter in its entirety for much the same reasons as the judgment in Van Erk $v$ Holmer ${ }^{104}$ where there was no longer any lis between the parties. Mercifully, in the opinion of the present author, it has not created a precedent and, contrary to its main goal, should not serve as guidance for future courts confronted with the same (non) issue.

The unfortunate judgment cannot even be excused on the basis that it amounted to a hard case. It is simply bad in law. The father never lived with the mother and only satisfied one of the three requirements listed in section 21(1)(b). The factual circumstances in this case could provide further support for the view that section 21(1)(b) should not be read disjunctively. I think it is fair to say that the legislator could never have intended to confer parental status on an unmarried father who displayed such indifference and lack of commitment. Had the court properly

would definitely not be the norm. The father would more often than not have to defend his position against the mother, as duly recognised in $\mathrm{s}$ $21(3)$ in terms of which the dispute must first be referred to mediation before a court is approached.

98 Idem par 19.

99 Ibid.

100 Idem par 20.

101 Ibid.

102 Idem par 6.

103 Ibid.

10419922 SA 636 (W); see also B v S 19953 SA 571 (A) 578B-G. 
investigated the history of section 21 and given proper weight to the wording used in the section it would have realised that the father could in fact never have acquired any rights to interfere with in the first place and would simply have dismissed the application. Notwithstanding the fact that the unmarried father had never acquired any responsibilities and rights in respect of the child he has a common law duty to maintain the child based on their blood relationship and will remain so until the child becomes self-supporting. ${ }^{105}$

\section{Section 21(1)(b)(ii): Contribution Towards Upbringing of Child}

As far as contributing to the child's upbringing is concerned, the court in $R R S v D A L$ referred to the definition of 'upbringing' in the Concise Oxford Dictionary as meaning ' $[\mathrm{t}]$ he treatment and instruction received from one's parents through childhood'. The court concluded that the conduct of the unmarried father in question could not fall within this category as it amounted to no more than a few occasional visits over a relatively short period of time. The court did, however, concede that the child was perhaps still too young for any meaningful role in her upbringing.

In another attempt to give content to the term 'upbringing', the court in Rudi $v$ Sonja, ${ }^{106}$ in the first place, referred to the judgment in Jooste $v$ Botha ${ }^{107}$ wherein it was observed that the parent-child relationship consisted of two aspects - an economic aspect providing for the child's physical needs, and the intangible aspect providing for the child's psychological, emotional development needs. Kgoele J in Rudi v Sonja ${ }^{108}$ agreed with the present author's contention that 'upbringing', in the context of section 21, should be interpreted as pertaining to the intangible aspects of raising a child, such as the training, education, rearing or nurture of the child'. Supported by the dicta of Mothle J in $M v$ Minister of Police of the Government of the Republic of South Africa, ${ }^{109}$ the court indicated that the list of non-financial duties that a parent could perform was endless and that the word 'upbringing' in section 21 should thus be interpreted widely. ${ }^{110}$

Returning to the interpretation of section 21(1)(b)(ii), the court in I $v$ $C^{111}$ considered the requirements of good faith contributions to the child's upbringing for a reasonable period 'elastic concepts' that 'permit a range of considerations culminating in a value judgment as to what should be deemed reasonable'. Section 21(1)(b)(ii) and (iii) were distinguished on the basis that the former speaks to a child's upbringing and the latter speaks to expenses in connection with the maintenance of the child, which clearly relates to finances necessary for the maintenance of the child. ${ }^{112}$ The court held that section 21(1)(b)(ii) and (iii) should be read in conjunction with section 18(2) describing the incidences of parental responsibilities and rights. ${ }^{113}$ Section $18(2)(d)$ was said to find

105 Van der Vyver \& Joubert Persone-en Familiereg (1991) 627.

106 Rudiv Sonja supra $n 57$ at [16].

10720002 SA 199 (T) $201 \mathrm{D}-\mathrm{E}$.

108 Rudiv Sonja supra n 57 at [16]. 
expression in section 21(1)(b)(iii) as the responsibility and the right 'to contribute to the maintenance of the child' while section 18(2)(a) and (b) (relating to care and contact) find expression in section 21(1)(b)(ii) which deals with the child's upbringing. ${ }^{114}$ According to Gabriel AJ, 'upbringing' had a far wider meaning than the dictionary meaning imputed to the term in RRS $v$ DAL:

I am of the view that the concept of "upbringing" denotes more. At its minimum contributing toward a child's upbringing encompasses personal effort towards interacting, caring for and being in contact with the child. But the concept could entail more such as a father procuring suitable care or educational aids or other material yet useful comforts for a child to ensure a comfortable and good upbringing. ${ }^{115}$

Testing the unmarried father's conduct in terms of this broader view of 'upbringing' the court ultimately concluded that the father had made a sufficient contribution for the following reasons: The father's involvement in the child's life began before his birth and continued up to the mother's departure. ${ }^{116}$ The fact that the duration of this period was only four months should be seen in the context of the young age of the child, the acrimony between the parents and the fact that the mother frustrated the father's efforts at contact. ${ }^{117}$

On appeal, the SCA in $K L V C v$ SDI also deemed it significant that the word 'contribute(s)' in sections 21(1)(b)(ii) and (iii) is not qualified in any way. ${ }^{118}$ The court deduced that '[c]learly, the legislature deliberately

10920135 SA 622 (GNP) [22]. Although not directly concerned with the responsibilities and rights of unmarried fathers, the judgment in $M v$ Minister of Police of the Government of the Republic of South Africa held great promise for children wishing to enforce their right to parental care against third parties who unlawfully deprived them of such care. In this case the father of two legitimate children died as a result of injuries sustained while wrongly incarcerated by the SAP. The mothers claimed constitutional damages on behalf of their minor children for the unlawful deprivation of their father's care. The judgment effectively overturned the much criticised precedent in Jooste $v$ Botha supra $n 107$ at 210G in which the court refused to award compensation to a child born out of wedlock for having been deprived of love and care by his famous father. However, the SCA has overturned the judgment. The SCA in Minister of Police $v$ Mboweni 2014 (6) SA 256 (SCA) [25] acknowledged the far-reaching ramifications if the decision of the court a quo was to be sustained. The SCA rejected the misguided and contradictory arguments used in the high court in a logical and convincing judgment. While a detailed discussion of the case is beyond the scope of this comment the case will have a huge impact on how the right to parental care lends itself to enforcement in future.

110 Idem par 17, agreeing with a similar conclusion reached by the present author (see Louw (LLD thesis) supra $\mathrm{n} 2$ at 123).

111 Iv C supra $\mathrm{n} 47$ at par 35.

112 Idem par 36.

113 Idem par 37.

114 Idem ar 38.

115 Idem par 39.

116 Idem par 46.

117 Idem parr 41-47.

118 KLVC V SDI supra n 48 at par 21. 
omitted to prescribe that the contributions must, for example, be reasonable, significant or material'. The fact that the word 'contribute(s)' in the section is in the present continuous tense was also deemed of some significance in as much as it conveys, in the court's view, 'that whatever the unmarried father contributes must be of an on-going nature'. The court also concluded that as the section stipulates that the contributions or attempts must endure for a reasonable period, 'what constitutes a reasonable period in the circumstances must be determined with reference to inter alia the age of the child and the circumstances of the parties at the time the determination is made'. ${ }^{119}$ The court found further evidence of the father's contribution in the fact that he had introduced the child to his extended family and took out an endowment policy to cater for the child's future upbringing. ${ }^{120}$ The fact that the father allegedly abused drugs and alcohol, was violent, aggressive and on one occasion came to visit the child whilst in possession of a firearm was considered, correctly in the author's view, irrelevant to the requirement in section 21(1)(b)(ii). ${ }^{121}$ Section 21 is not concerned with the best interests of the child but with the acquisition of parental responsibilities by the father. The fact that he is violent and aggressive can be grounds for the termination of his responsibilities and rights should they pose a danger to the welfare of the child, but should not impede the initial acquisition of rights. Apart from getting married to the birth mother, the parental status of married fathers is not made subject to further conditions. ${ }^{122}$ The court thus deemed it necessary to warn against unfairly discriminating against unmarried fathers by denying them responsibilities and rights "entirely unrelated to his ability and commitment as a father'. ${ }^{123}$ The approach adopted in this instance would therefore confirm the view expressed by the court in KLVC $v$ $S D I^{124}$ to the effect that it is an entirely factual enquiry.

\section{Section 21(1)(b)(iii): Maintenance}

As far as contributing to the maintenance of the child is concerned, the court in RRS $\mathcal{V} D A L$ determined objectively, despite the father's contentions to the contrary, that he had in actual fact never made any financial contributions to the child. The court in $I \mathcal{v} C$ drew attention to the largely indistinguishable difference in the wording between section 21(1)(b)(iii), which speaks of 'expenses in connection with the maintenance of a child', and section 21(2), which simply refers to the 'maintenance of the child'. ${ }^{125}$ Baby-sitting, so as to prevent the costs of a baby-sitter or the costs of a nanny, was mentioned as an example of an impecunious contribution towards the expenses in connection with the

119 Ibid.

120 Idem par 27.

121 Idem par 24.

122 S 20 of the Children's Act.

123 KLVC $v$ SDI supra $\mathrm{n} 48$ at par 20; see also Louw 'Constitutionality of a biological father's recognition as a parent' 2010 PER 175-183.

124 Idem par 14

125 I v C supra $\mathrm{n} 47$ at par 48. 
maintenance of the child. ${ }^{126}$ Accompanying the mother on some of the prenatal visits to the doctor and offering to pay for the costs of the pregnancy were regarded as contributions to the maintenance of the child because it not only related to the well-being of the mother but also related to the health and well-being of the child. ${ }^{127}$ Further evidence of financial contributions towards the maintenance of the child was found, inter alia, in the fact that the father had built a changing table, ${ }^{128}$ had bought certain items from Baby City $^{129}$ and a pram and car seat worth just over R10 $000^{130}$ and contributes to a monthly endowment policy and an education policy set up for the child. ${ }^{131}$ Evidence of attempts at making financial contributions was found in the offer to put the child on his medical aid ${ }^{132}$ which the mother declined, and to pay a contribution towards the child's maintenance costs ${ }^{133}$ which did not materialise because the mother failed to furnish the father with her banking details.

On appeal against the decision in $I v C$, the SCA in KLVC $v$ SDI emphasised that the requirement of a contribution towards maintenance had to be considered against the backdrop of two important factors, namely that section 21(2) of the Children's Act makes it plain that this requirement does not affect the duty of a father to contribute towards the maintenance of the child and, secondly, that the extent and nature of the contribution is again unqualified in the legislation. ${ }^{134}$ Thus the submission by the mother that the contribution by the father was insignificant and that it had to be viewed in the context of maintenance as envisaged in the Maintenance Act, in the court's view, was clearly misconceived. ${ }^{135}$

\title{
4 Conclusion
}

The judgments referred to in the discussion above confirm the widely acknowledged, and increasingly evident fact that section 21 of the Children's Act has far from clarified the position of unmarried fathers specifically and most importantly as far as the possible disjunctive reading of section 21 (1)(b) is concerned. In addition to the uncertainty it has created, the author has also - in a previous article - attacked the section on constitutional grounds as unfairly discriminating against not only the unmarried father but the mother and the child as well. ${ }^{136}$ The fear that automatic rights conferred on fathers could disrupt the established relationship between mother and child and place the onus on

\author{
126 Ibid. \\ 127 Idem par 49. \\ 128 Idem par 50. \\ 129 Idem par 51. \\ 130 Idem par 52. \\ 131 Idem par 54. \\ 132 Idem par 57. \\ 133 Idem par 58. \\ 134 KLVC $\mathcal{V}$ SDI supra $\mathrm{n} 48$ at par 29. \\ 135 Idem par 29. \\ 136 Louw 2010 PER 156.
}


the mother to enlist the help of the courts to protect her rights, is misplaced. ${ }^{137}$ Once again, a distinction should be drawn between the acquisition of rights and the exercise of those rights. Neither the birth mother nor the married father has to qualify to acquire parental responsibilities and rights. The married father qualifies based on his willingness to formally commit to the birth mother. Section 21 in practice now, in addition, regards commitment in the form of cohabitation as sufficient. To accept a marriage certificate or cohabitation as sufficiently indicative of a commitment to the child makes a mockery of recognising only meritorious fathers. ${ }^{138}$ The dividing line between such supposedly committed fathers and other biological fathers is simply too artificial to be justified. Not even the ultimate goal of achieving substantial equality for mothers who are most often the primary caregivers of the children can justify the inequitable impact of the section. As far as the exercise of parental responsibilities and right is concerned, the present author cannot see why unmarried mothers should be treated differently from married parents or parents who cohabitated at the birth of the child. ${ }^{139}$ Surely in all such cases the only question should be what is in the best interests of the child? If the father disrupts the child's life, then there is an onus on all interested parties to protect the child's interests. If this person is the mother, why should it make a difference whether she is or was married or lived with the father? Why should married mothers bear the onus of approaching the courts in such cases but unmarried mothers not? Mothers and fathers should be recognised on an equal basis as the legal parents of the child at birth, based simply on their biological connection. If this option is deemed too radical, the legal position of unmarried fathers in the United Kingdom and Australia can be emulated. In both these countries the registration of the father on the birth certificate of the child simultaneously confers legal responsibilities and rights on that father. ${ }^{140}$

An indifferent father will not interfere with the mother's parenting or decisions - evident from the facts in GMv KI. ${ }^{141}$ If the father is in fact interested in taking part in his child's life and he and the mother cannot agree on how to co-exercise their responsibilities and rights, there are a variety of options available to resolve such disputes. The parents can mediate their differences or draw up and register a parenting plan to serve as a guideline for both parents. ${ }^{42}$ As a last resort, the court can be called upon to determine what is in the best interests of the child. Section 21 merely creates a diversion from what should be the main concern -

137 See Louw (LLD thesis) supra $\mathrm{n} 2$ at 93.

138 See e.g. Fraser v Children's Court, Pretoria North supra n 51 at par 29.

139 Or a mother who shares responsibilites and rights with a section 21 qualified father.

140 See s 4(1)(a) of the U.K. Children Act 1989 and s 69R of the Australian Family Law Act 1975, read in conjunction with s $61 \mathrm{~B}$ explaining the meaning of 'parental responsibility'.

141 Discussed in par 3222 above.

142 Ss $33 \& 34$ and regs 9-11 of the General Regulations Regarding Children, 2010 published in GG 33076 GN R261 2010-04-01. 
devising a way of allowing the child to develop and maintain a meaningful relationship with both parents. The automatic acquisition of parental responsibilities and rights at the birth of the child has nothing to do with what is in the best interests of the particular child ${ }^{143}$ - it is merely a factual enquiry leaving the court with no discretion. ${ }^{144}$ The exercise of parental responsibilities and rights, on the other hand, has everything to do with what is in the specific child's best interests and is entirely in the discretion of the court. If parents are given the same responsibilities and rights at birth, the only kind of dispute that could arise between them would relate to the exercise of those responsibilities and rights which is entirely dependent on the child's best interests. A father should at least be given the opportunity to show himself (un)worthy. Excluding him legally from the child's life in an arbitrary fashion on a mere technicality such as not actually having lived with the mother at the time of the child's birth, or not having sufficiently or for a long enough period contributed to the child's upbringing and maintenance, seems unconscionable. Conferring legal parental status on both biological parents at birth could, however, create problems for a mother who wishes to travel abroad with the child - especially if the father's name appears on the child's birth certificate. Since the father who is identified on the birth certificate would also have acquired guardianship at birth, his consent would have to be obtained. If the father refuses consent, a high court order for substitute consent would be required. While it may be considered unfair to impose such an additional burden on an unmarried mother, it will in fact only place her in the same legal position as a married mother ${ }^{145}$ who must obtain the consent of her spouse (and often, more problematically, her ex-spouse) as co-guardian to take the child out of the country. ${ }^{146}$

Until such time as section 21 is found to be unconstitutional and declared invalid it unfortunately remains central to determining the parental status of unmarried fathers. While the courts were initially slow to acknowledge the changing legal position of unmarried fathers, the judiciary seems to have become overzealous in its attempt to accommodate such fathers. ${ }^{147}$ The interpretational guidance provided by the courts will be of some use but it cannot, in the view of this author, compensate for the lack of objective criteria to determine the continued limping parental condition of unmarried fathers.

143 Confirmed in LB v YD 2009 (5) SA 463 (T) par 43.

144 KLVC $v$ SDI supra $\mathrm{n} 48$ at par 14.

145 Or a mother who shares parental responsibilities and rights with a section 21-qualified biological father.

146 See s 18(3)(c)(iii) of the Children's Act.

147 Compare the steadfast insistence by Kgomo JP that the unmarried father had acquired no rights in the orders leading up to the judgment in FS v JJ 20113 SA 126 (SCA) par 33, with the blanket acceptance by Fisher AJ in GM $v$ KI supra $\mathrm{n} 4$ at par 3 that the unmarried father had in fact acquired those rights. 